Journal of Clinical Investigation

Vol. 42, No. 6, 1963

\title{
ACUTE RESPIRATORY DISEASE IN NORMAL VOLUNTEERS ASSOCIATED WITH COXSACKIE A-21 VIRAL INFECTION. III. RESPONSE TO NASOPHARYNGEAL AND ENTERIC INOCULATION
}

\author{
By ANDERSON SPICKARD, HUGH EVANS, VERNON KNIGHT, AND \\ KARL JOHNSON \\ (From the Laboratories of Clinical Investigations and of Infectious Diseases, National Insti- \\ tute of Allergy and Infectious Diseases, Bethesda, Md.)
}

(Submitted for publication August 23, 1962; accepted February 21, 1963)

Four strains of an unclassified human virus were isolated in 1958 by Lennette, Fox, Schmidt, and Culver and given the name Coe virus (1). This agent multiplied in tissues of human but not of simian origin, and could not be adapted to serial propagation of suckling mice. Subsequently, Pereira and Pereira demonstrated that the virus was approximately $25 \mathrm{~m} \mu$ in diameter, ether-resistant, and enterovirus-like in cytopathic effect in human tissue culture (2). Further serologic testing has shown the Coe virus to be indistinguishable from the enterovirus Coxsackie A-21 (3). In addition to the initial isolation from military recruits by Lennette and associates, Coxsackie A-21 has been isolated by others from throat specimens of military personnel with mild respiratory illness (4-7).

Parsons, Bynoe, Pereira, and Tyrrell (8) conducted a volunteer study using Coxsackie A-21 virus and showed that this agent could produce a mild upper respiratory illness in young adults after an incubation period of 2 to 4 days. Virus was detected in pharyngeal specimens over a 6-day period of observation, but was less often found in fecal specimens. In two recent reports $(5,6)$, Coxsackie A-21 virus was associated with mild upper respiratory illness in military personnel at Camp Lejeune, North Carolina. Virus was readily recovered from pharyngeal specimens of ill recruits, and significant rises in neutralizing and hemagglutination-inhibiting antibodies were demonstrated.

The evidence that this agent was a cause of human disease suggested the need for additional knowledge of its effects in man. Accordingly, studies were made in normal volunteers in which virus was administered by the nasopharyngeal route, or directly into the intestinal tract in sub- jects with no, intermediate, or high titers of homologous antibody. The study revealed that nasopharyngeal inoculation of subjects without measurable prechallenge antibody was followed by a systemic illness with fever and myalgia that was more severe when the inoculum was large. The presence of intermediate amounts of antibody before inoculation was associated with a syndrome of common cold, whereas men with high titers exhibited no illness. It was also found that the agent, although designated an enterovirus, was isolated most frequently from throat swabs. This finding was confirmed when it was found that direct intestinal inoculation produced only transient infection and no illness or antibody response. These findings are described in the following report.

\section{METHODS}

l'oluntecrs. The men who participated in these experiments were volunteers from several federal correctional institutions. Selection was based on willingness to participate, good health, and on the presence of a suitable level of antibody to Coxsackie A-21 for a particular experiment.

Clinical studies. Men were confined 3 per room for 3 to 4 days before and 3 weeks after viral inoculation. Examinations of the volunteers were made twice daily by two physicians who were unaware of the virus to be given, or of the antibody status of individual volunteers. Diagnosis of illness was made in a volunteer only by mutual agreement of both examiners. Oral temperatures were taken four times a day, and significant fever was considered to be any temperature greater than $37.5^{\circ} \mathrm{C}\left(99.5^{\circ} \mathrm{F}\right)$. Initial preinoculation leukocyte counts, sedimentation rate, and hemoglobin determination were obtained and then repeated on days $1,2,3,5$ to 9 , and 12 to 15 after inoculation. A urine analysis was performed before and once after inoculation. Studies of liver function including bilirubin, alkaline phosphatase, transaminase, Bromsulphalein retention, thymol turbidity, and cephalin flocculation were made before and 3 days after inoculation. Electrocardiograms and chest roentgeno- 
grams were taken before inoculation and repeated during any observed illness.

Bacteriological procedures. Nose and throat swabs were inoculated on sheep blood agar and into thioglycollate broth. Species identification was carried out by routine methods.

Viral specimens. Methods of specimen collection are reported in a previous publication (9). Fecal specimens were collected daily when available for 3 weeks from a number of men without preinoculation antibody. They were ground in a glass tissue-grinder to make a $10 \%$ suspension in normal saline. The suspension was then centrifuged at $10,000 \mathrm{rpm}$ for 30 minutes, and the supernatant fluid decanted and stored in a mechanical freezer at about $-60^{\circ} \mathrm{C}$.

Quantification of nasal secretions. Nasal secretions were collected from each man on paper tissues for a 7 to 10-day period after administration of virus. The weight of secretions was determined by weighing the used tissues and subtracting from that value the weight of a like number of unusued tissues of the same type.

Preparation and administration of iiral inoculum. The strain of Coxsackie A-21 employed in this study was recovered in human embryo tissue culture from a marine recruit at Camp Lejeune, North Carolina, in October, 1960, and its identity (strain 49882) was confirmed by neutralization with specific hyperimmune guinea pig antiserum. The preparation of the anti-Coxsackie A-21 guinea pig serum and the details of the neutralization test are reported in a previous publication (5). Safety-testing of a viral pool for use in our volunteers has been described previously (9). The viral pool used was the human embryo tissue culture fluid harvested after inoculation of the original throat specimen.

Inoculation of virus was performed by a physician not assigned to perform daily examinations of the volunteers. Approximately $1 \mathrm{ml}$ of inoculum was sprayed into the nose and throat with a hand nebulizer delivering a coarse spray. With the volunteer in the supine position, an additional $0.5 \mathrm{ml}$ was instilled into each nostril. The original viral pool was diluted 1:1,000 to provide material for inoculation. Simultaneous titration of the inoculum in human embryo tissue culture indicated that the amount of virus given to the volunteers in $3 \mathrm{ex}-$ periments with the lower dose averaged about 3,000 TCID $_{50}$.

Other volunteers were given a hundredfold greater concentration of virus by the nasopharyngeal route as described above, or directly into the lumen of the small bowel either in freshly prepared no. 0 gelatin capsules, ${ }^{1}$ containing $0.1 \mathrm{ml}$ of viral suspension enclosed in no. 1 gelatin capsules, or in liquid form by Rehfuss tube. The capsules were coated by dipping in a $10 \%$ solution of cellulose acetate hydrogen phthalate in acetone. ${ }^{2}$ After drying 10 minutes, they were given to volunteers. Simi-

1 Prepared by Mr. R. Crowley, Pharmacy Department, Clinical Center, National Institutes of Health, Bethesda, Md.

2 Distillation Products, Rochester, N. Y. lar capsules containing $\mathrm{BaSO}_{4}$ were observed by fluoroscopy to rupture in the small bowel usually 2 to 3 hours after administration. Assay of capsules prepared in this way showed good recovery of virus.

As control of enteric administration procedures, 320,$000 \mathrm{TCID}_{50}$ of Sabin type 1 oral polio vaccine was administered to three men via enteric coated capsule. The subjects were selected for absence of type 1 polio virus antibodies at a dilution of $1: 8$ as measured in a metabolic inhibition test. ${ }^{3}$

Virus isolation and identification. Primary isolation attempts from throat, rectal, and stool specimens were made by inoculation of $0.4 \mathrm{ml}$ of fluid into individual tubes of primary human embryo kidney cultures. Cultures were placed on a rotating drum (12 revolutions per hour) and observed daily for 9 to 13 days for cytopathic effect. Incubation temperature was $33^{\circ}$ to $34^{\circ} \mathrm{C}$. Tubes inoculated with rectal and fecal specimens were allowed to incubate 12 to 15 hours, the maintenance fluid was removed, and cultures were washed 3 times to reduce toxic effects on the cell sheets. Fluids were renewed every 3 days, and positive cultures were harvested when cytopathic changes were complete.

Cytopathic agents were tested for the presence of hemagglutinins for human type $\mathrm{O}$ erythrocytes at $4^{\bullet} \mathrm{C}$ as previously described (10). The hemagglutination-inhibition test was employed for primary identification of the last throat and rectal or fecal isolate obtained from each volunteer. All other isolates were considered to be Coxsackie A-21 if they produced the characteristic cytopathic effect in tissue culture and were demonstrated to hemagglutinate human type 0 cells at $4^{\circ} \mathrm{C}$.

Serology. Neutralization and hemagglutination-inhibition tests were carried out according to the methods previously described $(5,11)$.

\section{RESULTS}

\section{Response to nasopharyngeal inoculation of the smaller dose (about 3,000 TCID $D_{\tilde{5} 0}$ )}

The agent was given to 30 men in 3 separate experiments. Since patterns of illness, viral shedding, and serologic response appeared dependent on prechallenge homologous antibody status, the volunteers were divided into three groups by this criterion for comparison. In the no-antibody, intermediate-antibody, and highantibody groups, preinoculation neutralizing antibody and hemagglutination inhibition titers were, respectively: $<1: 4$ and $<1: 10,1: 4$ to $1: 128$ and $1: 10$ to $1: 40$, and $>1: 128$ and $\geq 1: 40$. The different responses of these three groups to

\footnotetext{
3 Performed by Dr. William Uhlendorf, Division of Biologics Standards, National Institutes of Health, Bethesda, Md.
} 
TABLE I

Relation of immune status to viral excretion and respiratory illness in volunteers inoculated with Coxsackie A-21 virus

\begin{tabular}{|c|c|c|c|}
\hline \multirow[b]{3}{*}{$\begin{array}{l}\text { Neutralizing antibody titers } \\
\text { Hemagglutination inhibi- } \\
\text { tion titers }\end{array}$} & \multicolumn{3}{|c|}{ Prechallenge antibody status } \\
\hline & None & Intermediate & High \\
\hline & $\begin{array}{l}<1: 4 \\
<1: 10\end{array}$ & $\begin{array}{l}1: 4 \text { to } 1: 128 \\
1: 10 \text { to } 1: 40\end{array}$ & $\begin{array}{l}>1: 128 \\
\geq 1: 40\end{array}$ \\
\hline No. of subjects & 13 & 6 & 11 \\
\hline \multicolumn{4}{|l|}{$\begin{array}{l}\text { No. of subjects with positive } \\
\text { cultures for virus }\end{array}$} \\
\hline $\begin{array}{l}\text { Throat } \\
\text { Rectal }\end{array}$ & $\begin{array}{l}13 \\
12\end{array}$ & $\begin{array}{l}\mathbf{6} \\
\mathbf{3}\end{array}$ & $\begin{array}{l}5 \\
1\end{array}$ \\
\hline \multicolumn{4}{|l|}{ Mean days of viral excretion } \\
\hline $\begin{array}{l}\text { Throat } \\
\text { Rectum }\end{array}$ & $\begin{array}{r}16.5 \\
4.0\end{array}$ & $\begin{array}{l}5.0 \\
4.0\end{array}$ & 5.0 \\
\hline \multicolumn{4}{|l|}{$\begin{array}{l}\text { No. of isolations during } \\
\text { period of viral excretion }\end{array}$} \\
\hline $\begin{array}{l}\text { Throat specimens, } \\
\text { no. positive/no. tested }\end{array}$ & $123 / 142$ & $26 / 30$ & $11 / 18$ \\
\hline $\begin{array}{l}\text { Rectal specimens, } \\
\text { no. positive/no. tested }\end{array}$ & $29 / 142$ & $9 / 30$ & $4 / 18$ \\
\hline Throat/rectal ratio & 4.2 & 2.9 & 2.7 \\
\hline \multicolumn{4}{|l|}{ Respiratory illness } \\
\hline $\begin{array}{l}\text { Total subjects ill } \\
\text { Febrile illness }\end{array}$ & $\begin{array}{l}8 \\
6\end{array}$ & $\begin{array}{l}4 \\
1\end{array}$ & $\begin{array}{l}\text { None } \\
\text { None }\end{array}$ \\
\hline
\end{tabular}

the nasopharyngeal inoculation of Coxsackie A-21 virus is emphasized in this report.

Patterns of viral excretion were strongly influenced by prechallenge antibody status. As shown in Table I, virus was recovered from all volunteers in the no- and intermediate-antibody groups (13 and 6 men), but from only 5 of 11 men ( $45 \%$ ) in the high-antibody group, demonstrating the limiting effect of high levels of prechallenge antibody on viral recovery.

Also shown in Table I are the mean time in days of viral excretion in the throat and rectal specimens of all three antibody groups. The mean time of viral excretion in the throat of the no-antibody group was 16.5 days, whereas it was 5 days for both the intermediate- and high-antibody groups. The mean time of viral excretion in the rectum in the first two groups was 4 days; in the high-antibody group, virus was recovered from rectal specimens in only one volunteer, from days 3 to 7 .

Further illustration of the limiting effect of homologous antibody on viral excretion was obtained by examining the percentage of volunteers positive for virus each day after viral inoculation. This temporal pattern of viral excretion in the throat and rectum in each of the three antibody groups is illustrated in Figure 1. Virus was recovered from the throat of most subjects who were devoid of antibody by day 2 after inoculation. The peak incidence of detectable rectal virus excretion occurred 2 to 3 days later. It may also be seen that throat specimens were still positive in $75 \%$ of the no-antibody group 14 days after virus inoculation, whereas no isolations were recorded in the other two groups after day 10. A similar curtailment in rectal virus shedding was observed in the intermediate- and high-antibody groups. The viral isolation rate from throat specimens far exceeded that from rectal specimens in all groups.

In order to test the efficiency of viral recovery from the lower gastrointestinal tract, stool specimens were collected from 6 men with no preinoculation antibody. The frequency of viral recovery from these samples was then compared with viral isolation from throat and rectal specimens from these same men. The results of this comparison are described in Table II, which is divided into two periods, one from days 2 to 7 after viral inoculation and the other from days 8 to 16 . In both periods, the number of throat isolations from each volunteer usually exceeded the number of isolations from the feces or rectal swab. No specimens were positive before day 2 . The number of isolations from feces exceeded the number from rectal specimens during each period. Virus was present in feces about as often as it was in the throat in the later period.

Patterns of neutralizing and hemagglutinationinhibiting antibody responses. Neutralizing anti-

TABLE II

Viral recovery from throat, rectal, and fecal specimens in 6 volunteers without preinoculation antibody*

\begin{tabular}{|c|c|c|c|c|c|c|}
\hline \multirow[b]{2}{*}{ Subject } & \multicolumn{3}{|c|}{ Days 2 to 7} & \multicolumn{3}{|c|}{ Days 8 to 16} \\
\hline & Throat & Feces & Rectum & Throat & Feces & Rectum \\
\hline 1 & $5 / 6$ & $2 / 6$ & $1 / 6$ & $4 / 4$ & $4 / 4$ & $1 / 4$ \\
\hline 2 & $4 / 6$ & $1 / 4$ & $0 / 6$ & $4 / 4$ & $3 / 4$ & $2 / 4$ \\
\hline 3 & $4 / 6$ & $0 / 1$ & $1 / 5 \dagger$ & $2 / 4$ & $0 / 1$ & $0 / 4$ \\
\hline 4 & $5 / 6$ & $4 / 5$ & $0 / 6$ & $2 / 4$ & $3 / 7$ & $0 / 4$ \\
\hline 5 & $4 / 6$ & $0 / 3$ & $1 / 6$ & $4 / 4$ & $1 / 5$ & $2 / 4$ \\
\hline 6 & $6 / 6$ & $0 / 4$ & $0 / 6$ & $1 / 4$ & $0 / 3$ & $1 / 4$ \\
\hline Totals & $23 / 36$ & $7 / 23$ & $3 / 35$ & $14 / 24$ & $11 / 24$ & $6 / 24$ \\
\hline Percentage & 78 & 30 & 9 & 58 & 46 & 25 \\
\hline
\end{tabular}

* Ratios represent no. of specimens positive/no. of specimens tested. Throat and rectal specimens were collected the same day, and stools whenever available.

$\dagger$ One specimen toxic to tissue cultures. 

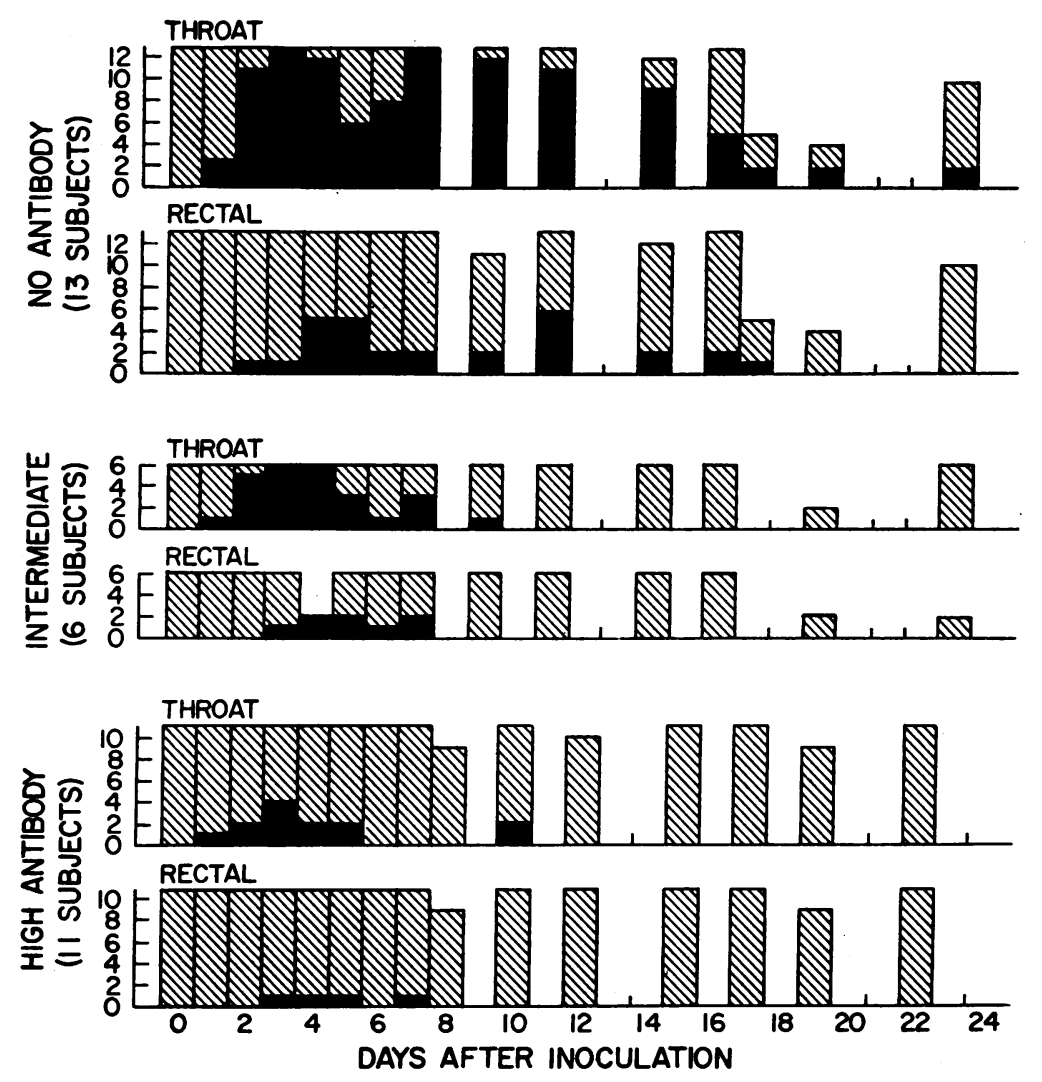

Aulture negative

Culture positive Coxsackie A-2I

Fig. 1. Temporal patterns of viral excretion in the throat and RECTUM AFTER INOCULATION OF COXSACKIE A-21 VIRUS IN THREE GROUPS OF VOLUNTEERS WITH DIFFERENT LEVELS OF PREINOCULATION NEUTRALIZING AND HEMAGGLUTINATION-INH IBITING ANTIBODY.

body responses after viral challenge are illustrated in Figure 2. There were 13 men with no detectable antibody before viral challenge. With one exception, there was no detectable response 1 week after inoculation; by 2 weeks, however, the mean titer had risen to $1: 16$, with a further significant rise at 3 weeks to $1: 64$. The 6 men in the intermediate-antibody group displayed a different pattern of antibody response. By 1 week, the mean titer of the group had changed only slightly from the prechallenge level of about $1: 32$, but at 2 weeks the mean titer had risen almost to its maximal value of $1: 1,024$, demonstrating a significant "booster" response. In the high-antibody group, there was no change in the mean titer 3 weeks after viral challenge (titers at 1 and 2 weeks did not change).
Figure 3 illustrates similar patterns of response by the hemagglutination-inhibition test. In the no-antibody group, significant antibody rise was observed at 2 weeks, with an additional rise 1 week later. In the intermediate-antibody group, the maximal rise occurred by 2 weeks, with no additional rise by 3 weeks, and in fact, a slight fall in the mean was observed.

Patterns of respiratory illness observed after viral challenge. Prechallenge antibody status also appeared to be important in determining the clinical consequences of infection. Thus, 8 of 13 volunteers in the no-antibody group had clinical illness, and 6 of the illnesses were marked by the occurrence of fever (Table I). Four of the 6 men in the intermediate-antibody group were ill, but only one had fever. Significantly, no clinical 


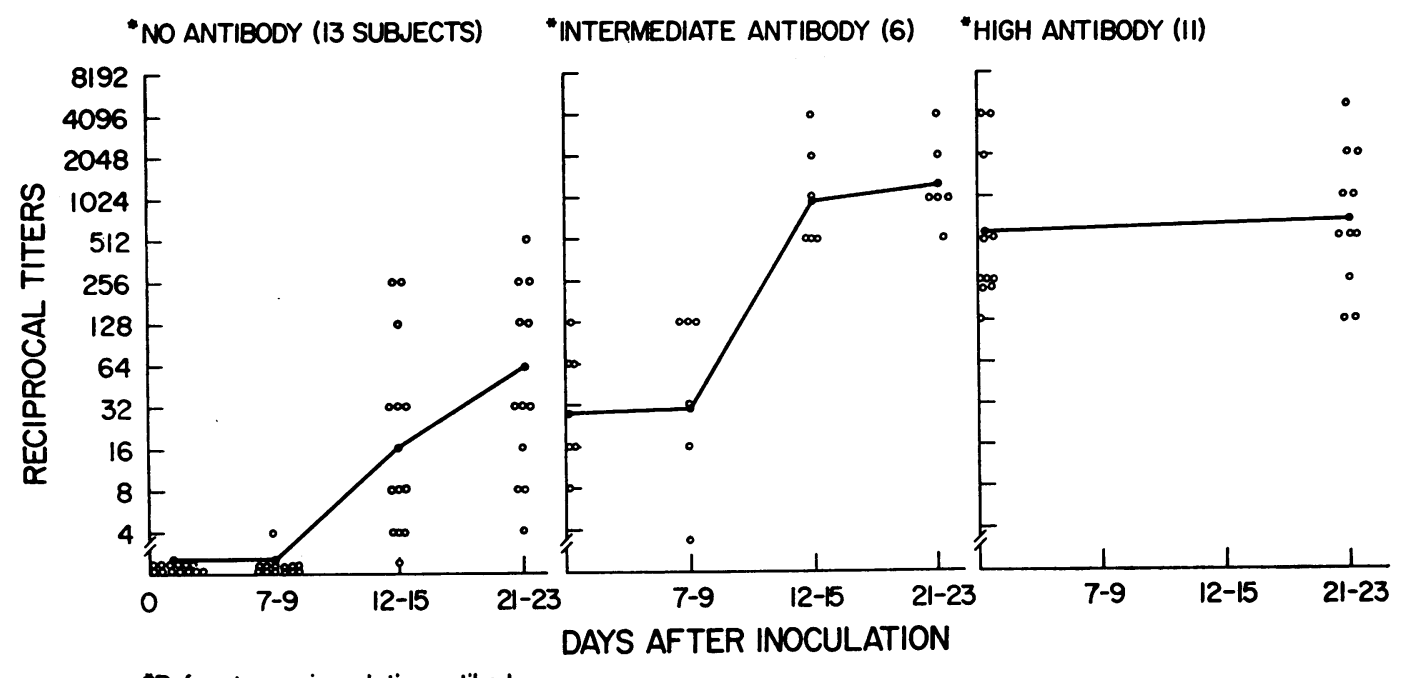

"Refers to pre-inoculation antibody

Fig. 2. Neutralizing antibody responses of volunteers inoculated with Coxsackie A-21 virus. Open circles represent individual serum specimen titers. The solid line connects the geometric mean titers of a group.

illnesses were observed in the high-antibody group.

The signs and symptoms of respiratory disease observed in the volunteers varied from a mild illness resembling a "common cold" to a syndrome indistinguishable from viral influenza. No evidence of exanthemata or meningitis was noted. A comparison of the illnesses observed in the noantibody group with those in the intermediateantibody group is summarized in Table III. Eight of the 13 men in the no-antibody group and 4 of the 6 men in the intermediate-antibody group were judged to be ill. In the no-antibody group, the total number of ill days was 18 with a mean of 2.3 days. A slightly shorter duration of illness was observed in the men in the intermediate-antibody group (mean of 1.7 days ill). A comparison of the occurrence of symptoms and fever in these two antibody groups is summarized in the rest of the table. Fever, malaise, headache, and myalgia were more common in the no-antibody group. Rhinorrhea was commonly experienced by most men in both groups. Sneezing was a frequent symptom in the men in the intermediate-

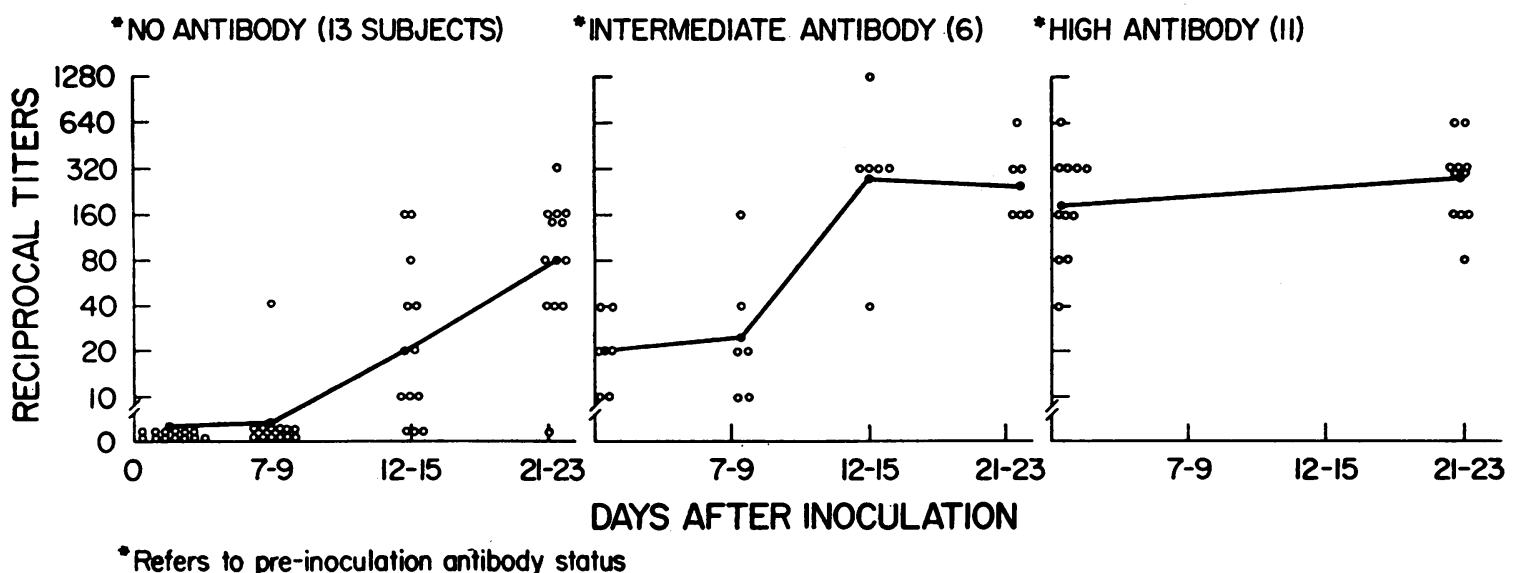

Fig. 3. Hemagglutination-inhibition antibody responses of volunteers inoculated with Coxsackie A-21 viRUs. Open circles represent individual serum specimen titers. The solid line connects the geometric mean titer of a group. 
TABLE III

Comparison of clinical illnesses in volunteers with different preinoculation antibody titers

\begin{tabular}{lcc}
\hline \hline & No antibody & $\begin{array}{c}\text { Intermediate } \\
\text { antibody }\end{array}$ \\
\hline Total subjects ill & 8 of 13 & 4 of 6 \\
Total days ill & 18 & 7 \\
Means days ill & 2.3 & 1.7 \\
Symptom, days observed & \\
total days ill & \\
Rhinorrhea & $15 / 18$ & $7 / 7$ \\
Sneezing & $15 / 18$ & $5 / 7$ \\
Malaise & $15 / 18$ & $3 / 7$ \\
Myalgia & $13 / 18$ & $2 / 7$ \\
Headache & $8 / 18$ & $2 / 7$ \\
Anorexia & $8 / 18$ & $0 / 7$ \\
Chilly sensation & $5 / 18$ & $0 / 7$ \\
Fever >37.5 $>$ C & $9 / 18$ & $1 / 7$ \\
\hline
\end{tabular}

antibody group, but anorexia and a "chilly" sensation, frequent complaints in those in the no-antibody group, were never observed in the intermediate-antibody group.

These data indicated that the level of prechallenge antibody influenced the pattern of clinical illness observed after inoculation with this viral agent. The no-antibody group responded to viral challenge by developing an influenza-like illness, whereas the intermediate-antibody group experienced a modified illness undistinguishable from the common cold.

Nasal secretions. Further contrasts in patterns of illness in the no- and intermediate-antibody groups were detected when the daily weights of nasal secretions were determined (Table IV). Increase in nasal secretion corresponded closely to illness when illness coexisted. The intermediate-antibody group (4 of the 6 men were ill)

TABLE IV

Nasal secretions (in grams) during 8 days after inoculation with Coxsackie $A-21^{*}$

No homologous antibody before challenge (10 subjects): $.10, .60 \dagger, 1.20 \dagger, 2.35,4.25,4.55,5.40,9.60,30.95 \dagger, 40.60$

Intermediate titers of homologous antibody before challenge ( 6 subjects):

$6.80 \dagger, 13.70,15.85,20.50 \dagger, 51.90,401.80$

High titers of homologous antibody before challenge (11 subjects, none became ill) :

$0,0,0,0, .70, .80,1.10,1.25,2.15,4.15,9.45$

* Wilcoxon two-sample test (two-sided) : 1) no antibody against intermediate antibody- $U=9, p<.05$ and 2) no antibody against high antibody-U $=23, \mathrm{p}>.10$.

† Did not become ill. showed a pronounced and significant increase in daily nasal secretion over the no-antibody group. This increase was uniform, and the two men with no illness had values that were also considerably increased. These findings suggest that nasal secretion may increase in response to viral infection in the absence of clinical illness. Average weight of secretions increased slightly for the 10 men in the no-antibody group ( 7 were ill) for whom these data were available, owing largely to 2 men (30.95 and $40.60 \mathrm{~g}$ ), only one of whom was ill. The response of these two resembles that of the intermediate-antibody group, and it is possible that they had had some previous experience with Coxsackie A-21 that was not revealed by hemagglutination-inhibiting or neutralizing antibody tests. There was little detectable nasal secretion from the 11 men with high antibody titers and no illness.

Leukocyte counts. The total leukocyte and neutrophil counts in the no-antibody group from 7 ill men who received the smaller inoculum and from the 2 ill men who received the larger inoculum are compared with results from 18 men without illness derived from the high- and intermediateantibody groups (Figure 4). The changes are not large in any group, but there is a significant rise and fall in the neutrophil count in the ill group $(\mathrm{p}=<0.05$, Wilcoxon two-sample test) and a significant fall in the total leukocyte count in the same group (days 1 to $3, p=<0.05$ ). The 4 men in the intermediate-antibody group who became ill showed no significant changes (not shown).

Other observations. Nose and throat cultures revealed no change in the bacterial flora after viral inoculation in any volunteer. Chest roentgenograms, electrocardiograms, urine analysis, hemoglobin, hematocrit, sedimentation rate, and tests of liver function remained normal in all volunteers after inoculation.

\section{Response to nasopharyngeal inoculation of a large dose $(320,000$ TCID 50}

The results of this experiment are summarized in Table V. Two of 5 men in the high-antibody group were not infected, as judged by viral recovery, illness, or antibody response. One subject in the intermediate-antibody group was in- 


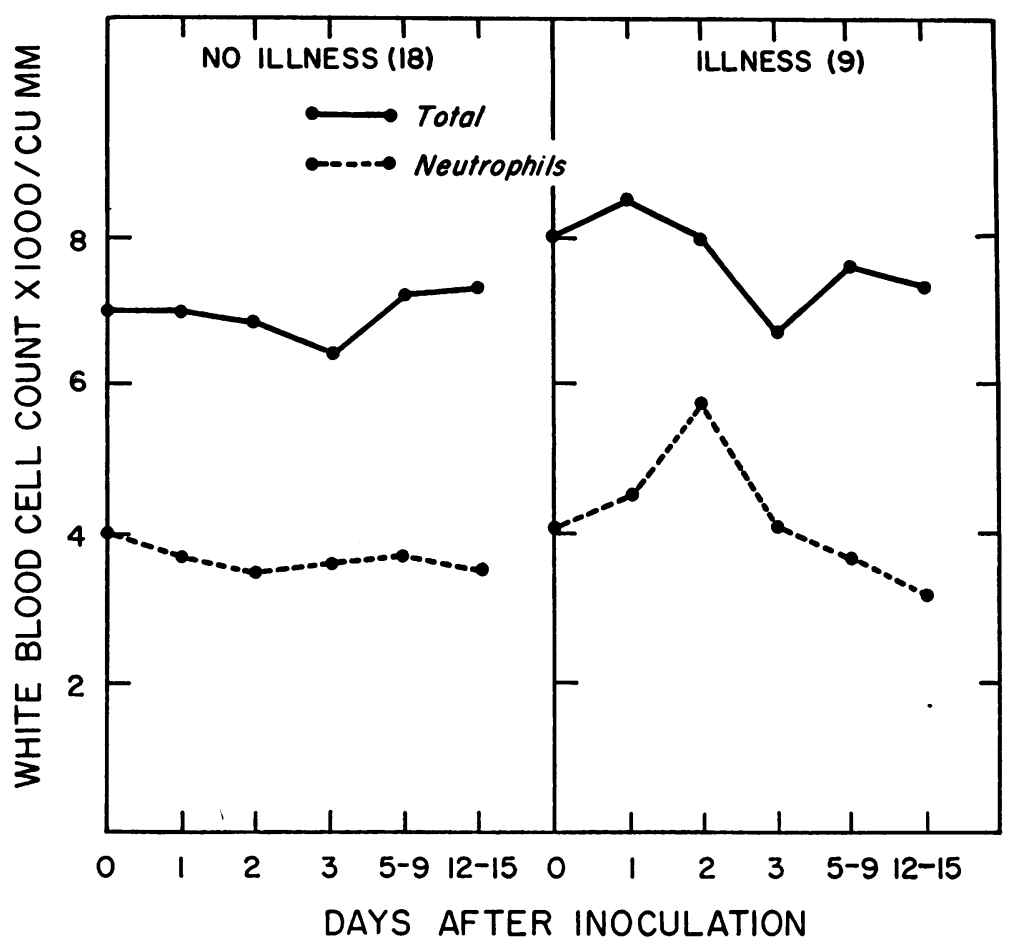

Fig. 4. Mean total Leukocyte and neutrophil counts in volunteers inoculated with CoXsackie A-21.

fected without exhibiting clinical manifestations. Virus was detected in throat specimens for 4 days, and there was a further increase in both neutralizing and hemagglutination-inhibiting antibodies to Coxsackie A-21 virus. Titers of $\geq 1: 512$ and $\geq 1: 320$, respectively, were observed within 7 days after inoculation, indicative of a rapid "booster" response to infection.

Two men without detectable homologous antibodies experienced moderately severe clinical illnesses. These began rather abruptly about 36 hours after inoculation and were characterized by fever up to $40.6^{\circ} \mathrm{C}$, severe frontal headache, anorexia, and generalized myalgia that was particularly marked in the posterior cervical and back muscles. There were no abnormal neurologic signs. The clinical course of C.V., the more severely ill of these two subjects, is illustrated in Figure 5. This man had 3 distinct episodes of fever between days 2 and 8 after administration of virus. A fine, macular rash was noted over the upper anterior thorax, the arms, and face on days

TABLE V

Clinical and labortory findings in 5 volunteers after administration of large dose of Coxsackie A-21 virus $(320,000$ TCID 50 ) via respiratory route

\begin{tabular}{|c|c|c|c|c|c|c|c|}
\hline \multirow[b]{2}{*}{ Subject } & \multicolumn{2}{|c|}{ Prechallenge antibody titer } & \multirow[b]{2}{*}{ Illness } & \multirow[b]{2}{*}{ Fever } & \multirow{2}{*}{$\begin{array}{l}\text { Virus detected, } \\
\text { pharynx }\end{array}$} & \multicolumn{2}{|c|}{ Antibody titer (4 weeks) } \\
\hline & HI* & Neut. $\dagger$ & & & & HI & Neut. \\
\hline $\begin{array}{l}\text { C.V. } \\
\text { A.S. } \\
\text { J.T. } \\
\text { G.W. } \\
\text { G.S. }\end{array}$ & $\begin{array}{c}<1: 10 \\
<1: 10 \\
1: 20 \\
\geq 1: 320 \\
\leq 1: 320\end{array}$ & $\begin{aligned}<1: 4 \\
<1: 4 \\
1: 128 \\
\geq 1: 512 \\
\geq 1: 512\end{aligned}$ & $\begin{array}{l}+ \\
+ \\
0 \\
0 \\
0\end{array}$ & $\begin{array}{l}+ \\
+ \\
0 \\
0 \\
0\end{array}$ & $\begin{array}{r}\text { days } \\
\geq 40 \\
\geq 25 \\
4 \\
0 \\
0\end{array}$ & $\begin{array}{c}\geq 1: 320 \\
1: 10 \\
\geq 1: 320 \\
\geq 1: 320 \\
\geq 1: 320\end{array}$ & $\begin{array}{l}\geq 1: 128 \\
1: 8 \\
\geq 1: 512 \\
\geq 1: 512 \\
\geq 1: 128\end{array}$ \\
\hline
\end{tabular}

* Hemagglutination inhibition.

$\dagger$ Neutralization of 32 TCID $_{50}$. 
2 and 3. Although there was no swelling or edema, he also experienced definite, symptomatic testicular tenderness during the initial febrile reaction.

Lumbar punctures were performed on both men on day 2 after inoculation. Cerebrospinal fluid pressure, and sugar, protein, and chloride concentrations were within normal limits. No cells or organisms were detected on microscopical examination. Cultures for bacteria were negative, and no virus was isolated in human embryo tissue or monkey kidney cell cultures. Results of a repeated cerebrospinal fluid examination of C.V. on day 5 were within normal limits, and Coxsackie A-21 virus was not recovered from the fluid.

Attempts to isolate Coxsackie A-21 virus from blood and urine also were unsuccessful. Three-ml volumes of whole clotted blood were obtained on days 2,3 , and 4, ground in a Ten Broeck homogenizer, and inoculated into 6 human embryo tissue cultures. Morning urine specimens collected daily for the first week after inoculation were centrifuged at $120,000 \times g$ for 90 minutes, and the sediments assayed in human embryo tissue cultures. Cultures inoculated with blood or urine specimens did not develop cytopathic changes during a 14day observation period. Despite these failures, however, virus was recovered from the oropharynx of both men from nearly every specimen obtained during the entire interval that each was available for observation. In contrast, virus was detected in rectal specimens on only one occasion. Neither volunteer showed any detectable neutralizing antibodies 12 days after administration of virus, but such substances were demonstrable at the end of the third week.

\section{Intestinal administration of virus}

All volunteers employed in these studies were without detectable antibodies to the virus. In a preliminary experiment, approximately 320 $\mathrm{TCID}_{50}$ was administered in enteric coated cap-

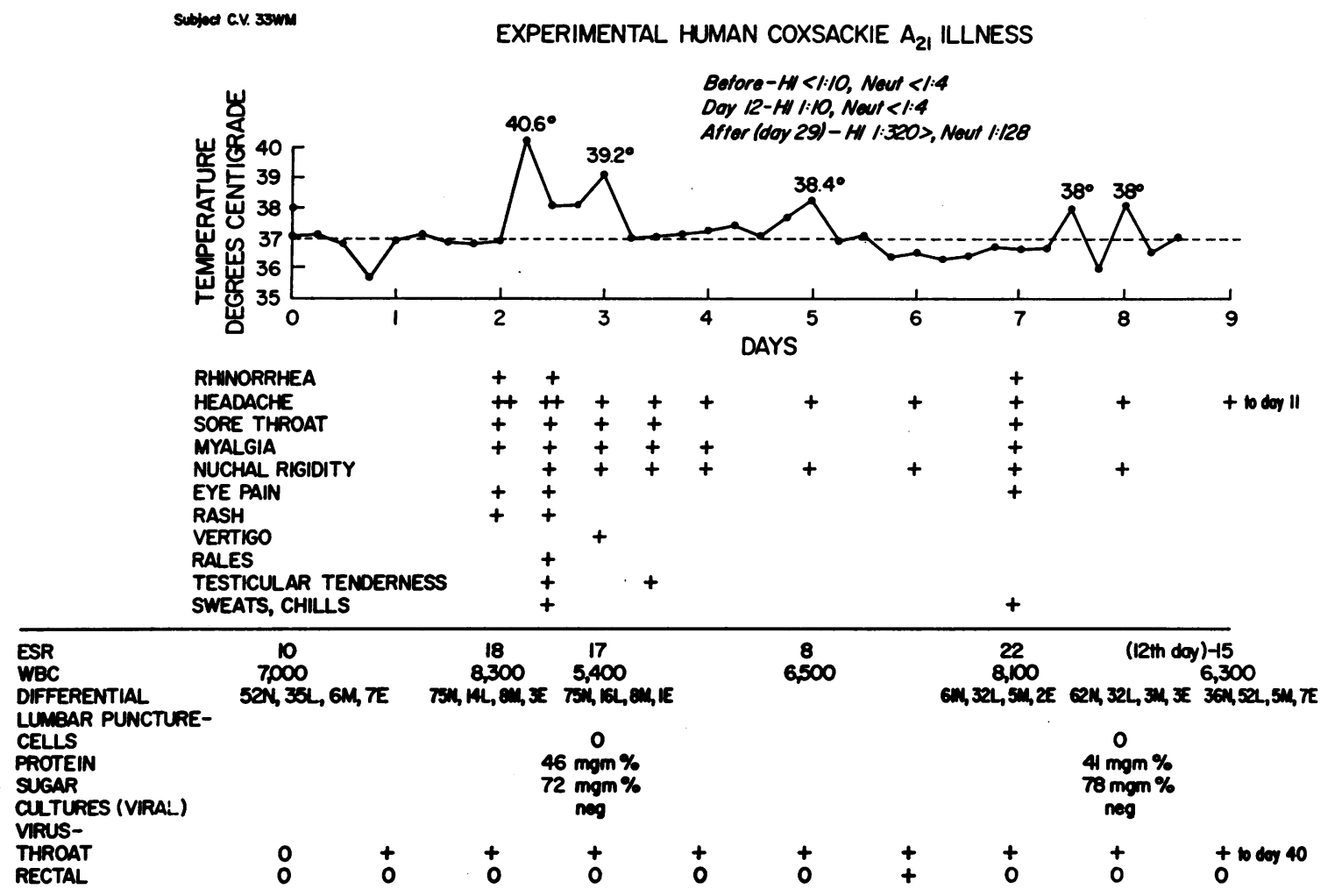

hoculum-320,000 TC10 50 HK, Coxeockis $A_{21}$

Fig. 5. Course of illness in subject C.V. after nasopharyngeal inoculation with 320,000 TCID 50 of CoxSACKIE A-21 vIRUS. 
TABLE VI

Responses of volunteers given large dose of Coxsackie A-21 or polio 1 virus by gastrointestinal route

\begin{tabular}{|c|c|c|c|c|c|}
\hline \multirow[b]{2}{*}{ Virus administered } & \multirow[b]{2}{*}{ Subject } & \multicolumn{2}{|c|}{ Virus recovered from } & \multicolumn{2}{|c|}{$\begin{array}{l}\text { Reciprocal neutralizing } \\
\text { antibody titer to virus } \\
\text { administered* }\end{array}$} \\
\hline & & Rectal swab & Feces & Day 0 & Day 35 \\
\hline $\begin{array}{l}\text { Coxsackie A-21, } 10^{5.5} \mathrm{TCID}_{50} \\
\quad\left(320,000 \mathrm{TCID}_{50}\right)\end{array}$ & $\begin{array}{l}\text { C.G. } \\
\text { R.R. } \\
\text { J.G. } \\
\text { T.B. } \\
\text { L.C. } \\
\text { R.F. } \\
\text { T.L. } \\
\text { S.P. } \\
\text { R.T. }\end{array}$ & $\begin{array}{c}\text { day } \\
0 \\
0 \\
0 \\
13,16 \\
0 \\
0 \\
0 \\
0 \\
0\end{array}$ & 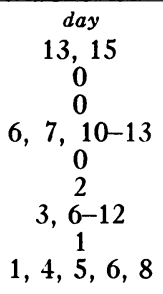 & $\begin{array}{l}<4 \\
<4 \\
<4 \\
<4 \\
<4 \\
<4 \\
<4 \\
<4 \\
<4\end{array}$ & $\begin{array}{l}<4 \\
<4 \\
<4 \\
<4 \\
<4 \\
<4 \\
<4 \\
<4 \\
<4\end{array}$ \\
\hline Polio $1,10^{6} \mathrm{TCID}_{50}$ & $\begin{array}{l}\text { A.C. } \\
\text { M.L. } \\
\text { F.S. }\end{array}$ & $\begin{array}{c}3,4,6,8,9,12 \\
7,14 \\
0\end{array}$ & $\begin{array}{l}\text { Not tested } \\
\text { Not tested } \\
\quad 2\end{array}$ & $\begin{array}{l}<4 \\
<4 \\
<4\end{array}$ & $\begin{array}{r}32 \\
8 \\
<4\end{array}$ \\
\hline
\end{tabular}

$* 32$ TCID $_{50}$ in tests.

sules to 3 volunteers. No symptoms ensued, virus was not recovered from rectal or oropharyngeal specimens, and neutralizing antibodies failed to appear 4 weeks after feeding. In each case, radiologic study revealed integrity of the $\mathrm{BaSO}_{4}$ marker capsule in the stomach, with subsequent breakdown in the upper small intestine.

Nine men were next fed a larger quantity of virus $\left(300,000 \mathrm{TCID}_{50}\right), 7$ via enteric coated capsules and 2 via Rehfuss tube. No signs or symptoms of illness attributable to the virus were observed, and virus was not recovered from pharyngeal swabs. The patterns of intestinal excretion of virus and serologic responses of these men are presented in Table VI. Similar data for 3 men given type 1 oral poliovirus vaccine are also shown. Coxsackie A-21 virus was recovered from rectal swabs only once. Stool specimens, however, yielded a total of 23 isolates from 6 of the 9 subjects. Volunteers R.R. and J.G., who were inoculated via Rehfuss tube, failed to excrete detectable virus. In contrast, type 1 polio virus was detected in rectal specimens from 2 of 3 subjects given the vaccine.

None of the volunteers fed Coxsackie A-21 virus developed neutralizing antibodies to the agent, whereas 2 of 3 volunteers fed polio virus developed significant elevations in neutralizing antibody.

\section{DISCUSSION}

These results suggest that clinical response to Coxsackie A-21 viral infection may be related to viral dose in addition to homologous antibody status. Although a small dose of virus produced mild, influenza-like illnesses in volunteers similar to those reported in cases of naturally occurring infection $(1,4,6,7,12)$, a large amount of the same virus evoked a more severe reaction marked by a clinical (although not laboratory) picture of aseptic meningitis, together with a rash and symptoms suggestive of orchitis. Aseptic meningitis, or exanthemata, or both have been observed in association with three Coxsackie A viruses, types 7,9 , and 16 (13-15). A somewhat similar pattern was produced in suckling mice by Coxsackie A-21 virus, in that small doses of the agent resulted in inapparent infection, whereas an inoculum of $10^{5}$ to $10^{6} \mathrm{TCID}_{50}$ regularly evoked paralysis and even death (16). In each case, this result could have been due to the presence of a mixture of particles in the viral pool, with the more virulent ones being diluted in preparation of the smaller inoculum. Distinct hemagglutinating and nonhemagglutinating particles have been detected in another Coxsackie A-21 viral pool prepared in primary human embryonic renal cells (17). Administration of at least 1,000 TCID $_{50}$ of each of these variants to suckling mice and to human volunteers, however, was not associated with the more severe disease produced by the large dose of "unpurified" virus (18).

The persistence of virus in the throats of nonimmune subjects for more than 2 weeks appears to be unique for a "respiratory" virus. Similar 
data have not been recorded for myxoviruses, respiratory syncytial virus, adenoviruses, or other enteroviruses or entero-like viruses found associated with respiratory illness. Because these latter agents are often undetectable at the end of a brief respiratory illness and before measurable circulating antibodies are observed, it has been postulated that nonimmunological host defense mechanisms may be crucial to the termination of infection by such viruses (19). Much has been written about the potential role of interferons in host defense against viruses, and experimental results with influenza virus in mice are compatible with this hypothesis (20). In this study, however, the excretion of Coxsackie A-21 virus continued for many days after clinical convalescence, and was usually terminated at about the time that circulating antibodies were first detected. Thus, if interferon exerted any effect, it did not appear to have been complete. It would be of interest to compare the in vitro sensitivity of Coxsackie A-21 virus to interferon with that of other "respiratory" viruses.

The illness observed in subjects with no detectable preinoculation antibody often simulated classical viral influenza, and there were no clinical features by which Coxsackie A-21 infection could have been specifically differentiated. The short (1- to 2-day) incubation period is also characteristic of other experimental enteroviral infections [ECHO 28 (21) and "rhinoviruses" (22)] and is similar to influenza (23). In contrast, incubation periods for respiratory syncytial virus (9), parainfluenza viruses (24-26), and adenoviruses $(27,28)$ may range from 3 to 7 days.

The absolute increase in neutrophils during the early phase of Coxsackie A-21 infection is in sharp contrast to the observations of Henle, Henle, and Stokes (23), who found a sharp drop in such cells at the peak of experimentally induced influenza infections. Many other viruses require similar study, however, before any assessment of the differential value of these findings can be made.

The prechallenge immunologic status of a volunteer was found to be critical in determining the biological and clinical sequelae to viral administration. Men with high antibody titers were quite resistant to infection, since none developed illness or significant immune response, and virus was rarely recovered. Lesser amounts of antibody did not prevent infection, but modified its form, as compared with that in persons without antibody, in at least three clearly recognizable respects. Illnesses were milder, less often accompanied by fever, and were marked by relatively increased amounts of nasal secretion. Recovery of virus from the pharynx was reduced both in frequency and duration. Finally, immune responses were quantitatively much greater. Parenthetically, the close correlation obtained in both neutralization and hemagglutination-inhibition tests suggests the possibility that both may measure the same antibody.

These data indicate that under certain conditions Coxsackie A-21 virus may produce reinfection and clinical illness in humans. Similar findings have been reported for respiratory syncytial virus (29) and parainfluenza viruses types 1 and $3(26,30)$. In contrast, recent studies with two other enteroviruses, ECHO 28 (21) and HGP (31), a "rhinovirus" antigenically distinct from but similar in properties to $\mathrm{ECHO}$ 28 virus, indicated that detectable homologous antibody was associated with a marked degree of resistance to experimentally induced infection and illness. Although it is tempting to draw conclusions concerning the comparative biology of different "respiratory" viruses from such experimental work, many other variables have yet to be examined critically. It seems possible that a smaller inoculum than used in these experiments might have resulted in milder illnesses among men without antibody, and in no illness or serologic response among the intermediate-antibody group.

The results of enteric administration of the virus strongly indicate that the intestine is not the primary site of multiplication of Coxsackie A-21 virus in human adults. The sporadic recovery of virus from feces, the almost complete inability to detect the agent in rectal swabs, and the lack of antibody response are different from the results obtained using a $1 / 100$ dose of the same virus given by the respiratory route. In the latter instance, virus was readily recovered from the pharynx of each of 13 volunteers with no homologous antibodies before challenge, and neutralizing antibody responses were detected in 12 of these men. The data are consistent with 
observations on the relative recovery of the agent from pharynx and rectum in natural infections (5), and provide further evidence that Coxsackie A-21 virus is primarily a "respiratory" pathogen, probably spread from person to person by aerosol.

Very few enteroviruses have been etiologically associated with acute respiratory disease. In this context, the differential patterns of pharyngeal and fecal excretion of such agents is of some interest. Although polio viruses, and many other enteroviruses, have been recovered from the pharynx, available information indicates that many of them multiply for longer periods in the intestine. This is not the case for ECHO 28 virus, however, an agent that has also been associated with respiratory illness (32-34). Another possible exception is Coxsackie B-2 virus. This virus was isolated from the pharynx for at least as long as from feces of artificially infected chimpanzees (35), and has also been implicated as the etiologic agent in an outbreak of summer febrile illness in which respiratory symptoms were often observed (36). In this study, virus was recovered more frequently from throat than rectal specimens. The experimental examination of sites of multiplication of enteroviruses may thus provide useful clues for the study of the natural history of these viruses.

\section{SUM MARY}

Eight of 13 men without measurable antibody to Coxsackie A-21 virus, 1 to 2 days after nasopharyngeal inoculation with approximately 3,000 $\mathrm{TCID}_{50}$ of the agent, developed a 2- to 4-day influenza-like illness characterized by fever, myalgia, malaise, and rhinorrhea. . Four of 6 men with intermediate titers of homologous antibody responded to similar inoculation by developing a syndrome of common cold, with profuse rhinorrhea and few systemic manifestations. Eleven men with high titers of homologous antibody failed to become ill when challenged.

Men in the intermediate-antibody group who developed the common cold syndrome discharged large amounts of nasal secretion while ill, significantly more than the moderately increased secretion in those in the no-antibody group who developed the influenza-like illness. Men in the high- antibody group showed no increase in nasal secretion after inoculation.

Men in the no-antibody group experienced a significant rise and fall in the neutrophil count during illness and recovery, and also a significant decrease in total leukocyte count during recovery. The other two groups had no significant change in leukocyte counts after inoculation.

A larger dose of virus $\left(320,000 \mathrm{TCID}_{50}\right)$ by the nasopharyngeal route produced a more severe illness in 2 men in the no-antibody group, an illness characterized by severe myalgia, headache, fever, skin rash, and stiff neck, but negative findings in cerebrospinal fluid. One volunteer with intermediate and 2 with high titers of homologous antibody did not become ill when challenged with the larger dose of virus.

A fourfold rise in hemagglutination-inhibiting and neutralizing antibody occurred in a majority of volunteers with no measurable, or intermediate titers of antibody 12 to 15 days after challenge. The rise was considerably greater in subjects who had some antibody when challenged.

Virus was isolated frequently, and for as long as 3 to 6 weeks, from throat swabs of subjects with no homologous antibody at the time of challenge. Rectal swabs were less frequently positive, but for nearly as long a time. Volunteers with prechallenge antibody had much less viral infection.

Direct inoculation of the intestinal tract of volunteers with no homologous antibody by giving virus through a Rehfuss tube or in enteric coated capsules resulted in no illness, no positive throat cultures, and only transient intestinal infection as judged by cultures of stool (rectal swabs were less frequently positive). Furthermore, there was no homologous antibody detectable 35 days after inoculation in these subjects.

\section{REFERENCES}

1. Lennette, E. H., V. L. Fox, N. J. Schmidt, and J. O. Culver. The Coe virus, an apparently new virus recovered from patients with mild respiratory disease. Amer. J. Hyg. 1958, 68, 272.

2. Pereira, M. S., and H. G. Pereira. Coe virus. Properties and prevalence in Great Britain. Lancet 1959, 2, 539.

3. Schmidt, N. J., V. L. Fox, and E. H. Lennette. Immunologic identification of Coxsackie A21 virus 
with Coe virus. Proc. Soc. exp. Biol. (N. Y.) 1961, 107, 63.

4. Van der Veen, J., K. G. Oei, and A. Prins. Isolatie van Coe-virus bij patiënten met een acute aandoening van de luchwegen. Ned. T. Geneesk. 1960, $104,617$.

5. Johnson, K. M., H. H. Bloom, M. A. Mufson, and R. M. Chanock. Acute respiratory disease associated with Coxsackie A-21 virus infection. I. Incidence in military personnel: observations in a recruit population. Amer. med. Ass. 1962, 179, 112.

6. Bloom, H. H., K. M. Johnson, M. A. Mufson, and R. M. Chanock. Acute respiratory disease associated with Coxsackie A-21 virus infection. II. Incidence in military personnel: observations in a nonrecruit population. J. Amer. med. Ass. 1962, $179,120$.

7. McDonald, J. C., D. L. Miller, A. J. Zuckerman, and M. S. Pereira. Coe (Coxsackie A 21) virus, parainfluenza virus and other respiratory virus infections in the R.A.F. 1958-1960. J. Hyg. (Lond.) 1962, 60, 235.

8. Parsons, R., M. L. Bynoe, M. S. Pereira, and D. A. J. Tyrrell. Inoculation of human volunteers with strains of Coe virus isolated in Britain. Brit. Med. J. 1960, 1, 1776.

9. Kravetz, H. M., V. Knight, R. M. Chanock, J. A. Morris, K. M. Johnson, D. Rifkind, and J. P. Utz. Respiratory syncytial virus. III. Production of illness and clinical observations in adult volunteers. J. Amer. med. Ass. 1961, 176, 657.

10. Johnson, K. M., H. H. Bloom, L. Rosen, M. A. Mufson, and R. M. Chanock. Hemagglutination by Coe virus. Virology 1961, 13, 373.

11. Rosen, L. A hemagglutination-inhibition technique for typing adenoviruses. Amer. J. Hyg. 1960, 71, 120.

12. Fukumi, H., F. Nishikawa, T. Sonoguchi, and T. Shimizu. Isolation of Coe virus and some seroepidemiological surveys of Coe virus infections. Jap. J. med. Sci. Biol. 1961, 14, 21.

13. Grist, N. R. Isolation of Coxsackie A7 virus in Scotland. Lancet 1960, 1, 1054.

14. Habel, K., R. J. Silverberg, and A. Shelokov. Isolation of enteric viruses from cases of aseptic meningitis. Ann. N. Y. Acad. Sci. 1957, 67, 223.

15. Robinson, C. R., F. W. Doane, and A. J. Rhodes. Report of an outbreak of febrile illness with pharyngeal lesions and exanthem: Toronto, summer 1957-isolation of group A Coxsackie virus. Canad. med. Ass. J. 1958, 79, 615.

16. Mufson, M. A., H. H. Bloom, R. M. Chanock, and K. M. Johnson. Unpublished observations.

17. Johnson, K. M. and D. J. Lang. Separation of hemagglutinating and non-hemagglutinating variants of Coxsackie A-21 virus. Proc. Soc. exp. Biol. (N. Y.) 1962, 110, 653.
18. Lang, D. J., and K. M. Johnson. Unpublished observations.

19. Jackson, G. G., H. F. Dowling, L. W. Akers, R. L. Muldoon, A. Van Dyke, and G. C. Johnson. Immunity to the common cold from protective serum antibody. Time of appearance, persistence and relation to reinfection. New Engl. J. Med. 1962, 266, 791.

20. Issacs, A., and G. Hitchcock. Role of interferon in recovery from virus infections. Lancet 1960, 2, 69.

21. Jackson, G. G., H. F. Dowling, W. J. Mogabgab. Infectivity and interrelationships of 2060 and $\mathrm{JH}$ viruses in volunteers. J. Lab. clin. Med. 1960, 55, 331.

22. Tyrrell, D. A. J., and M. L. Bynoe. Some further virus isolations from common colds. Brit. Med. J. 1961, 1, 393.

23. Henle, W., G. Henle, and J. Stokes, Jr. Demonstration of the efficacy of vaccination against influenza type $\mathrm{A}$ by experimental infection of human beings. J. Immunol. 1943, 46, 163.

24. Reichelderfer, T. E., R. M. Chanock, J. E. Craighead, and R. J. Huebner, H. C. Turner, W. James, and T. G. Ward. Infection of human volunteers with type 2 hemadsorption virus. Science 1958, 128, 779.

25. Chanock, R. M., A. Vargosko, A. Luckey, M. K. Cook, A. Z. Kapikian, T. Reichelderfer, and R. H. Parrott. Association of hemadsorption viruses with respiratory illness in childhood. J. Amer. med. Ass. 1959, 169, 548.

26. Tyrrell, D. A. J., M. L. Bynoe, K. B. Petersen, R. N. P. Sutton, and M. S. Pereira. Inoculation of human volunteers with parainfluenza viruses types 1 and 3 (HA 2 and HA 1). Brit. Med. J. 1959, $2,909$.

27. Ward, T. G., R. J. Huebner, W. P. Rowe, R. W. Ryan, and J. A. Bell. Production of pharyngoconjunctival fever in human volunteers inoculated with APC viruses. Science 1955, 122, 1086.

28. Bell, J. A., T. G. Ward, R. J. Huebner, W. P. Rowe, R. G. Suskind, and R. S. Paffenbarger, Jr. Studies of adenoviruses (APC) in volunteers. Amer. J. Public Health, 1956, 46, 1130.

29. Johnson, K. M., R. M. Chanock, D. Rifkind, H. M. Kravetz, and V. Knight. Respiratory syncytial virus. IV. Correlation of virus shedding, serologic response, and illness in adult volunteers. J. Amer. med. Ass. 1961, 176, 663.

30. Chanock, R. M., D. C. Wong, R. J. Huebner, and J. A. Bell. Serologic response of individuals infected with para influenza viruses. Amer. J. pub. Hith 1960, 50, 1858.

31. Bynoe, M. L., J. Horner, G. C. Schild, D. Hobson, A. Kipps, and D. A. J. Tyrrell. Inoculation of human volunteers with a strain of virus isolated from a common cold. Lancet 1961, 1, 1194. 
32. Price, W. H., H. Emerson, I. Ibler, R. Lachaine, and A. Terrell. Studies of the JH and 2060 viruses and their relationship to mild upper respiratory disease in humans. Amer. J. Hyg. 1959, 69, 224.

33. Hamre, D., and J. J. Procknow. Virological studies in acute respiratory disease in young adults. I. Isolation of ECHO 28. Proc. Soc. exp. Biol. (N. Y.) 1961, 107, 770.

34. Johnson, K. M., H. H. Bloom, B. Forsythe, and R. M. Chanock. Unpublished observations.
35. Melnick, J. L., and A. S. Kaplan. Quantitative studies of the virus-host relationship in chimpanzees after inapparent infection with Coxsackie viruses. I. The virus carrier state and the development of neutralizing antibodies. J. exp. Med. 1953, 97, 367.

36. Heggie, A. D., I. Schultz, R. R. Gutekunst, M. Rosenbaum, and L. F. Miller. An outbreak of a summer febrile disease caused by Coxsackie B-2 virus. Amer. J. publ. Hlth 1960, 50, 1342. 